neofilolog

Czasopismo Polskiego Towarzystwa Neofilologicznego

ISSN 1429-2173, 2019, NR 53/2, 329-345

http://dx.doi.org/10.14746/n.2019.53.2.12

http://poltowneo.org/

Piotr J. Malinowski

Uniwersytet w Białymstoku https://orcid.org/0000-0002-8744-6229

p.malinowski@uwb.edu.pl

\title{
EVALUATION OF THE USE OF INFORMATION AND COMM UNICATION TECHNOLOGY IN ENGLISH COURSEBOOKS
}

\section{Ocena zastosowania technologii informacyjno-komunikacyjnych w podręcznikach do nauki języka angielskiego}

The aim of the article is to present an analysis of the assessment of the use of information and communication technology (ICT) in conventional textbooks for teaching English. After presenting the theoretical framework of the new core curriculum in terms of autonomy and ICT application, the study describes the way in which ICT tools are integrated or ignored in current English textbooks. The study covered textbooks used in the seventh grade of primary school. Six of the eight (one per publisher) textbooks available on the market were selected for this purpose.

Qualitative research comprised a thorough evaluation of tasks which comprised explicit references to ICT. The quality of the analysed didactic materials was determined by the potential level of supporting students' autonomy by using the coursebook tasks in question, measured through a specially designed Likert scale. The conclusions served to propose changes and improvements to these textbooks.

Keywords: coursebook, ICT, learner autonomy

Słowa kluczowe: podręcznik, TIK, autonomia ucznia 


\section{Introduction}

The 2016 education reform, which began to be effective as of the 2017/2018 school year, introduced major changes in the education system in Poland. As a result, the institution of middle school (or lower secondary, or junior high school) ceased to exist in August 2019. The three educational stages ( 6 yrs +3 $y r s+3 y r s)$, introduced in the reform of 1999 , consequently reverted to the former two schooling cycles $(8+4)$. Subsequently, a new National Core Curriculum for General Education ${ }^{1}$ (NCC) was devised because new entities appeared in the new system $-7^{\text {th }}$ and $8^{\text {th }}$ grades in primary school and $4^{\text {th }}$ in secondary school.

The exigency to implement the new NCC urged publishers to create completely new coursebooks, which inspired an idea for research: to perform an indepth, multi-aspect evaluation of all these new didactic materials, bearing in mind that busy teachers usually struggle to assess textbooks that might actually never meet the needs of their students. Thus, there were two main reasons for conducting such an analysis. First and foremost, teachers' departments that make decisions regarding which textbook to choose on a so-called "long-term basis" ${ }^{2}$ would obtain a useful assessment tool, since being able to evaluate a coursebook prior to its use is an important competence in the everyday work of an English teacher (Kusiak-Pisowacka, 2015: 71). This article aims to facilitate the process of coursebook selection, since the primary objective of the study was to verify which coursebooks (which had not been previously scrutinized by any investigation) might greatly support the enhancement and encouragement of learner autonomy for the reason that they refer to information and communication technology (ICT) tools in a way assumed to be the most effective. Secondly, the purpose of this paper is to suggest what improvements the authors themselves might be able to introduce in their publications either by altering later editions, or using the results of this research in creating new books.

The focus of the study was limited to one main topic: the development of learner autonomy through references to ICT in new textbooks for learning English in primary school, hence helping users become autonomous constituted the sole criterion of the coursebook evaluation described below. The reason for this lies in one of the results of a quantitative study on the use of ICT tools conducted on the same set of textbooks - nearly all the textbooks

\footnotetext{
${ }^{1}$ Polish act of law: Podstawa programowa wychowania przedszkolnego i kształcenia ogólnego (art. 4 pkt 24 Ustawy z dnia 14 grudnia 2016 r. - Prawo oświatowe (Dz.U. 2017 poz. 59 z dnia 11 stycznia 2017 r.).

${ }^{2}$ Each year different pupils use the same book since coursebooks are the property of the school and are not allowed to be written in.
} 
include a moderate number (between 5 to 9 ) of ICT-based ${ }^{3}$ tasks, with only one exception where the practical use of new technologies suggested in one textbook is almost imperceptible (Malinowski, 2018: 62). Hence the need to examine to what extent it is possible to develop learner autonomy through such assignments. As a result, other issues - such as developing digital literacy in accordance with the new NCC ${ }^{4}$ - are beyond the scope of the present text.

\section{Research rationale}

Not only does ICT have a significant impact on the quality of life (Sysło, et al., 2014: 10), but also on foreign language teaching. Learners expect language classes to integrate technology into teaching (Dudeney \& Hockly, 2007: $8)$, a tendency in line with the most recent recommendations ${ }^{5}$ for a broader inclusion of ICT into the syllabi of other subjects into the core curriculum, which will enable the development of digital literacy and literacy skills (RE, 2017: 8). According to the new NCC, one of the most important objectives which all primary schools are to attain is preparing students to learn a set of the ICT-related skills. The school is to equip students with the competences needed to make conscious and responsible choices when using various digital resources, together with the ability to critically analyze information available on the Internet, and safely navigate in digital space, knowing how to establish and maintain a respectful relationship with other network users (NCC, 2017: 7). To complete the picture, the use of educational projects is strongly advised (RE, 2017: 6) supported by the use of ICT (NCC, 2017: 8).

Modern schools are expected to create conditions that will enable learners to manage their process of learning. According to the requirements for teaching content for modern languages published in the new Core Curriculum, which strongly relates to the Common European Framework of Reference for Teaching Languages (2001, CEFR), students should be able to selfassess their work and use techniques to work independently on the language. They are expected to cooperate in a group (e.g. in lessons and in extracurricular language project work) and use sources of information in a modern foreign language. Students must be able to apply communication and compensation strategies when they do not know or cannot remember the word (NCC, 2017: 19). Summarising, schools are obliged to foster learner autonomy understood as "the ability to take charge of one's own learning" (Holec, 1981: 3)

\footnotetext{
${ }^{3}$ In which ICT tools must be used by students.

${ }^{4}$ This issue became the focus of another study by the author, (cf. M alinowski, 2019, 2019).

${ }^{5}$ In the Reform of Education presentation - RE.
} 
"accepting compromise, and engaging in peer teaching and peer assessment" (CEFR, 2001: 144), a practical competence useful not only in a foreign language. It is a recurring theme throughout both the new NCC and RE that such goals must be achieved with the use of ICT.

One of the ways of developing pupil autonomy emphasised in the NCC is undertaking project-based learning (PBL) tasks. Teachers are expected to encourage learners to work on their own using an appropriate range of films, Internet resources, books, communicators and social media suitable for their age, since such assignments may "strengthen the language potential of students to develop their self-confidence in the use of English in the real world, outside the classroom" (Fried-Booth, 2002: 5). The new NCC (2017: 7-8) highlights the fact that the acquisition of social competences - such as communication and collaboration in a group, including virtual environments - is of paramount importance for the development of a young person and his/ her successful adult life. This goal may be achieved by participating in team or individual projects and using ICT to perform such tasks (NCC, 2017: 8), as technology forms a platform for mutual "tuning" on the part of learners and their school (Dylak, 2012: 179).

ICT plays a significant role in the process of developing strategic learning and autonomy in students' work, which has regularly been noticed in Poland by a handful of academics. Strategy training, which has recently been verified by a comprehensive review of the latest research and analysis of foreign language learning strategies in the digital environment (Gajek and Michońska-Stadnik, 2017), may no longer be considered "a myth or at most wishful thinking rather than a fact" (Droździał-Szelest, 2008: 410). Krajka (2007: 17) believes Internet-assisted teaching to be "naturally conducive to the development of learner autonomy", with great help obviously coming from the teacher (2002). These opinions are shared by Konsek (2004) and Kruk $(2009,2011)$, who propose the development of student autonomy with the help of Internet resources. Additionally, Skweres (2011) and Strzemeski (2011) consider podcasts as an attractive medium in promoting autonomous language learning. Correspondingly, Widła (2009: 191) recognizes WebQuest as an example of working autonomously with the use of information technology in a foreign language lesson. Hofman (2008) in turn, notes the important role of information technology in promoting autonomy in the light of the theory of multiple intelligences, whereas Majer (2015) aims to demonstrate that electronic textbooks can be a way of fostering student autonomy.

Finally, the report on the implementation of the previous core curriculum (Marczak et al., 2015: 73) and the BENJA research on effectiveness of teaching English in Polish schools (Szpotowicz \& M uszyński, 2015: 100) both confirmed the fact that language teaching in Polish schools is predominantly coursebook-based, 
particularly in primary schools. Since coursebooks still dominate lessons of English, not only do they have to meet high ministerial standards, but they also ought to employ ICT tools in the learning process, because the inclusion of Internet and computer-based assignments in coursebooks allows a greater variety of in-class language tasks (Gajek, 2008: 75) and may help teachers to implement activities which significantly foster students' autonomy (Habrat, 2008: 290).

\section{Evaluation of the Use of Information and Communication Technology in English Coursebooks}

\subsection{Research material}

When it comes to textbooks used in English Language Teaching (ELT) for the last two classes ( $7^{\text {th }}$ and $8^{\text {th }}$ ) of the newly reorganised primary school, a total of eight such publications were issued ${ }^{6}$. M inisterial approval was given to all 8 new series of textbooks (Wykaz..., 2017), yet willingness to treat all publishers equally resulted in the random selection of one of the two textbooks offered each by Oxford and M acmillan. The alphabetical list of textbooks for the seventh grade of the new primary school includes the following (in brackets, an abbreviated name followed by the name of the publisher): All Clear (AC, M acmillan), Citizen Z (CZ, PWN-Cambridge University Press), English Class (EC, Pearson), English Plus Options (EPO, Oxford), Smart Time 1 (ST, Express Publishing), Teen Explorer (TE, Nowa Era/National Geographic).

\section{a. Research tools}

In order to put forward the idea of the ICT-based work included in the coursebooks, an operationalization of this construct (Wilczyńska \& M ichońskaStadnik, 2010: 287) has to be established. Thus, every time we refer to an ICTbased task, it means that there are explicit references to the use of ICT tools included in the instructions, for instance find on the Internet, record a vlog post, or create a multimedia presentation (Malinowski, 2018: 54).

The inventory of criteria against which each ICT-based coursebook task has been evaluated is the author's own construct rooted both in the strategic approach to foreign language teaching and in the results of a close scrutiny of the new Core Curriculum (NCC, 2017: 8, 25, 38). Efficient and responsible use of ICT enhancing the development of learner autonomy was a key factor in developing the catalogue

\footnotetext{
${ }^{6}$ When this research was being carried out (January 2018), only form VII coursebooks were available.
} 
presented below. The criteria were to examine whether by undertaking a particular task learners are:

1. encouraged to:

a. self-evaluate their own work,

b. use different techniques of learning,

c. shape creativity and a positive attitude to learning a foreign language,

d. learn about their own strengths,

e. develop interests and passions;

2. using:

a. project-based learning (PBL),

b. authentic source materials from the Internet,

c. tools based on information and communication technology.

Having analysed the requirements of the new NCC regarding the development of learner autonomy, the use of state-of-the-art technologies in ELT and the implementation of PBL work, a hypothesis was formulated that the newest textbooks at least partly meet the criteria for improving autonomy in students of the last years of primary school via the use of digital tools. This hypothesis is reflected in the following research questions: (1) Is it possible to develop learner autonomy through coursebook tasks with explicit references to ICT?, (2) What aspects of learner autonomy may be developed the most through such tasks?, (3) Which textbook may help to foster students' autonomy the most using ICT tools?

\section{b. Research procedure}

A qualitative approach to glottodidactic research has long been considered as "burdened by original sin" (Wilczyńska \& Michońska-Stadnik, 2010: 139-140, 285), since its major characteristic is that it is of a largely subjective nature. Therefore, in order to make the research results as objective as possible, the coursebooks underwent an internal assessment (M CDonough \& Shaw, 1993), or a micro evaluation (Ellis, 1997) of their pedagogical aspects (Kusiak-Pisowacka, 2015: 69).

\begin{tabular}{|l|c|}
\hline Coursebook & Number of ICT-based tasks \\
\hline All Clear & 5 \\
\hline Citizen Z & 0 \\
\hline English Class & 6 \\
\hline English Plus Options & 5 \\
\hline Smart Time & 15 \\
\hline Teen Explorer & 5 \\
\hline Total & $\mathbf{3 6}$ \\
\hline
\end{tabular}

Figure 1: Number of ICT-based tasks in the analysed coursebooks (M alinowski, 2018: 57). 
Evaluation of the use of information and communication technology in English...

All thirty-six ICT-based tasks (see Figure 1.) found in the coursebooks were meticulously evaluated. Each of the assignments was set against the aforementioned criteria using a Likert scale in an attempt to establish the rate of success in achieving steady progress towards a higher level of autonomy in learners who use such coursebook tasks. The procedure involved indicating the extent to which it was possible to agree with each criterion by marking a box corresponding to a PBL task with: 4 - strongly agree, 3 - agree, 2 - neither agree nor disagree, 1 - disagree, 0 - strongly disagree. This way each response option was assigned a number for scoring purposes and subsequently the scores for the items addressing the same PBL task were summed up and averaged (cf. Dörnyei, 2007: 105).

\section{c. Research results}

The results of the study have been organised into tables below. In order to ensure readability of results, Figure 2 has been divided into two smaller tables (Figures $2 \mathrm{a}$ and $2 \mathrm{~b}$ ). In the tables, both the task scores (organised horizontally) and the criteria scores (vertically) are presented together with the mean and the median, i.e. the measures of central tendency (cf. Dörnyei, 2007: 213214), which are also presented in a separate diagram (Figure 3). The ICT-based activities are used in five of the six coursebooks selected for the research study. One of the textbooks (CZ) contains no such tasks, hence it is not included.

\begin{tabular}{|c|c|c|c|c|c|c|c|c|c|c|}
\hline Coursebook/ page no./task details & la & $1 \mathbf{b}$ & lc & $1 d$ & le & $2 a$ & $2 b$ & $2 c$ & $\begin{array}{l}\frac{0}{8} \\
\frac{6}{5} \\
\text { है }\end{array}$ & $\begin{array}{l}\frac{0}{8} \\
\frac{10}{8} \\
\frac{8}{2}\end{array}$ \\
\hline \multicolumn{11}{|c|}{ All Clear (AC) } \\
\hline 40 prepare a multimedia presentation - sport disciplines & 0 & 3 & 4 & 2 & 4 & 4 & 4 & 4 & 3.13 & 4 \\
\hline 41 create a digital wall - a sport & 3 & 4 & 4 & 2 & 4 & 2 & 4 & 4 & 3.38 & 4 \\
\hline 74 write a quiz - books & 0 & 3 & 4 & 2 & 4 & 4 & 4 & 3 & 3 & 3.5 \\
\hline 108 create a poster - Polish pop music & 0 & 3 & 4 & 2 & 4 & 4 & 4 & 3 & 3 & 3.5 \\
\hline 109 prepare a presentation - music & 0 & 3 & 4 & 2 & 4 & 4 & 2 & 4 & 2.88 & 3.5 \\
\hline Mean score & 0.6 & 3.2 & 4 & 2 & 4 & 3.6 & 3.6 & 3.6 & 3.08 & \\
\hline Median score & 0 & 3 & 4 & 2 & 4 & 4 & 4 & 4 & & 4 \\
\hline \multicolumn{11}{|c|}{ English Class (EC) } \\
\hline 17 create a digital presentation - a dance in your country & 2 & 3 & 4 & 2 & 4 & 4 & 4 & 4 & 3.38 & 4 \\
\hline 41 prepare a quiz - endangered animals in Poland & 2 & 4 & 4 & 2 & 4 & 4 & 4 & 3 & 3.38 & 4 \\
\hline 43 make a digital presentation - pets in your country & 0 & 4 & 4 & 2 & 4 & 4 & 4 & 4 & 3.25 & 4 \\
\hline 67 prepare a presentation - unusual buildings in your country & 0 & 4 & 4 & 2 & 3 & 4 & 4 & 4 & 3.13 & 4 \\
\hline 93 presentation - a shopping area in your country & 0 & 4 & 4 & 2 & 4 & 4 & 4 & 4 & 3.25 & 4 \\
\hline 119 presentation - an environmental problem in your country & 0 & 4 & 4 & 2 & 3 & 4 & 4 & 4 & 3.13 & 4 \\
\hline Mean score & 0.67 & 3.83 & 4 & 2 & 3.67 & 4 & 4 & 3.83 & 3.25 & \\
\hline Median score & 0 & 4 & 4 & 2 & 4 & 4 & 4 & 4 & & 4 \\
\hline
\end{tabular}


Piotr J. Malinowski

\begin{tabular}{|l|c|c|c|c|c|c|c|c|c|c|c|}
\hline \multicolumn{1}{|c|}{ English Plus Options (EPO) } \\
\hline 120 write about an amazing athlete from your country & 0 & 2 & 2 & 2 & 4 & 0 & 4 & 1 & 1.88 & 2 \\
\hline 122 write about a young Polish entrepreneur & 0 & 2 & 2 & 2 & 4 & 0 & 4 & 1 & 1.88 & 2 \\
\hline 124 design and write a class blog & 3 & 4 & 4 & 4 & 4 & 4 & 4 & 4 & 3.88 & 4 \\
\hline 126 make an outdoor activity map & 3 & 4 & 4 & 4 & 4 & 4 & 4 & 4 & 3.88 & 4 \\
\hline 127 make a poster for scary activities in your country & 0 & 3 & 3 & 2 & 3 & 2 & 4 & 4 & 2.63 & 3 \\
\hline Mean score & 1.2 & 3 & 3 & 2.8 & 3.8 & 2 & 4 & 2.8 & $\mathbf{2 . 8 3}$ & \\
\hline Median score & 0 & 3 & 3 & 2 & 4 & 2 & 4 & 4 & & $\mathbf{3}$ \\
\hline
\end{tabular}

Figure 2a: Evaluation of ICT-based tasks in coursebooks - All Clear, English Class, English Class Options

\begin{tabular}{|c|c|c|c|c|c|c|c|c|c|c|}
\hline Coursebook/ page no./task details & la & $\mathbf{1 b}$ & lc & 1d & le & $2 a$ & $2 b$ & 2c & $\begin{array}{l}\frac{0}{8} \\
8 \\
\frac{g}{2} \\
\Sigma\end{array}$ & $\begin{array}{l}\frac{0}{8} \\
8 \\
\frac{0}{8} \\
\frac{8}{8} \\
\text { ह }\end{array}$ \\
\hline \multicolumn{11}{|l|}{ Smart Time(ST) } \\
\hline $\begin{array}{l}17 \text { prepare a PowerPoint presentation or a poster - favourite athletes } \\
\text { from your country }\end{array}$ & 0 & 3 & 4 & 2 & 4 & 2 & 2 & 42 & 2.63 & 2.5 \\
\hline 27 prepare a poster - strange houses around the world & 0 & 3 & 4 & 2 & 3 & 2 & 3 & 2 & 2.38 & 2.5 \\
\hline 38 prepare a poster - buildings in different shapes and materials & 0 & 3 & 4 & 2 & 3 & 2 & 3 & 2 & 2.38 & 2.5 \\
\hline 49 write an article - a children's charity in your country & 0 & 2 & 2 & 1 & 2 & 0 & 4 & 2 & 1.63 & 2 \\
\hline 59 collect information - a tribe & 0 & 3 & 3 & 2 & 3 & 2 & 4 & 2 & 2.38 & 2.5 \\
\hline 79 do some research - the history of space travel & 0 & 3 & 3 & 2 & 3 & 2 & 4 & 22 & 2.38 & 2.5 \\
\hline 81 write a short paragraph - an important event in your country's history & 0 & 2 & 2 & 2 & 3 & 0 & 4 & 2 & 1.88 & 2 \\
\hline 86 prepare a poster - famous monuments in your country & 0 & 3 & 4 & 2 & 3 & 2 & 3 & 2 & 2.38 & 2.5 \\
\hline 91 write a few sentences - ankylosaurus & 0 & 2 & 2 & 2 & 3 & 0 & 4 & 2 & 1.88 & 2 \\
\hline 91 prepare a presentation - why the dinosaurs died out & 0 & 2 & 2 & 2 & 3 & 2 & 4 & 22 & 2.13 & 2 \\
\hline 97 write a short summary of an animal myth from your country & 0 & 2 & 2 & 2 & 2 & 0 & 4 & 2 & 1.75 & 2 \\
\hline 102 prepare a PowerPoint presentation or a poster - reptiles & 0 & 3 & 4 & 2 & 3 & 2 & 3 & 42 & 2.63 & 3 \\
\hline 118 collect information - the Sun & 0 & 2 & 2 & 1 & 3 & 2 & 4 & 2 & 2 & 2 \\
\hline 123 write a few sentences - compare two New Year celebrations & 0 & 2 & 3 & 2 & 3 & 0 & 4 & 2 & 2 & 2 \\
\hline 129 write a short paragraph - a fruit or food festival in your country & 0 & 3 & 4 & 2 & 4 & 2 & 2 & 22 & 2.38 & 2 \\
\hline Mean score & 0 & 2.53 & 3 & 1.87 & 3 & 1.33 & 3.47 & 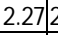 & 2.18 & \\
\hline Median score & 0 & 3 & 3 & 2 & 3 & 2 & 4 & 2 & & 2.5 \\
\hline \multicolumn{11}{|l|}{ Teen Explorer (TE) } \\
\hline 43 make a short vlog - your favourite Polish film & 4 & 4 & 4 & 4 & 4 & 4 & 3 & 4 & 3.88 & 4 \\
\hline 73 make a short vlog - your M aster Chef dish & 4 & 4 & 4 & 4 & 4 & 4 & 3 & 4 & $3.8 \mathrm{c}$ & 4 \\
\hline 102 search the Internet - instructions and manuals & 0 & 3 & 3 & 2 & 3 & 0 & 4 & 2 & 2.13 & 2.5 \\
\hline 103 make a short vlog - the manual how something works & 4 & 4 & 4 & 4 & 4 & 4 & 3 & 4 & 3.88 & 4 \\
\hline 133 make a short vlog - a dream job & 4 & 4 & 4 & 4 & 4 & 4 & 3 & 4 & 3.88 & 4 \\
\hline Mean score & 3.2 & 3.8 & 3.8 & \begin{tabular}{|l|}
3.6 \\
\end{tabular} & 3.8 & 3.2 & 3.2 & 3.63 & 3.53 & \\
\hline Median score & 4 & 4 & 4 & 4 & 4 & 4 & 3 & \begin{tabular}{l|l}
4 & \\
\end{tabular} & & 4 \\
\hline
\end{tabular}

Figure 2b: Evaluation of ICT-based tasks in coursebooks - Smart Time, Teen Explorer

For better reception of the overall results, the mean scores per criterion (Figure 3.) and per coursebook (Figure 4.) have been combined into the diagrams below, which clearly show the differences and similarities among both the coursebooks and the evaluation criteria. 
Evaluation of the use of information and communication technology in English...

\begin{tabular}{|l|c|c|c|c|c|c|c|c|}
\hline \multirow{2}{*}{ Coursebook } & \multicolumn{7}{|c|}{ Evaluation criteria } \\
\cline { 2 - 11 } & $\mathbf{1 a}$ & $\mathbf{1 b}$ & $\mathbf{1 c}$ & $\mathbf{1 d}$ & $\mathbf{1 e}$ & $\mathbf{2 a}$ & $\mathbf{2 b}$ & $\mathbf{2 c}$ \\
\hline All Clear & 0.6 & 3.2 & 4 & 2 & 4 & 3.6 & 3.6 & 3.6 \\
\hline English Class & 0.7 & 3.8 & 4 & 2 & 3.7 & 4 & 4 & 3.8 \\
\hline English Plus Options & 1.2 & 3 & 3 & 2.8 & 3.8 & 2 & 4 & 2.8 \\
\hline Smart Time & 0 & 2.53 & 3 & 1.87 & 3 & 1.33 & 3.47 & 2.27 \\
\hline Teen Explorer & 3.2 & 3.8 & 3.8 & 3.6 & 3.8 & 3.2 & 3.2 & 3.6 \\
\hline Mean score & $\mathbf{1 . 1}$ & $\mathbf{3 . 3}$ & $\mathbf{3 . 6}$ & $\mathbf{2 . 5}$ & $\mathbf{3 . 7}$ & $\mathbf{2 . 8}$ & $\mathbf{3 . 7}$ & $\mathbf{3 . 2}$ \\
\hline
\end{tabular}

Figure 3: Mean scores of ICT-based tasks in coursebooks per criterion.

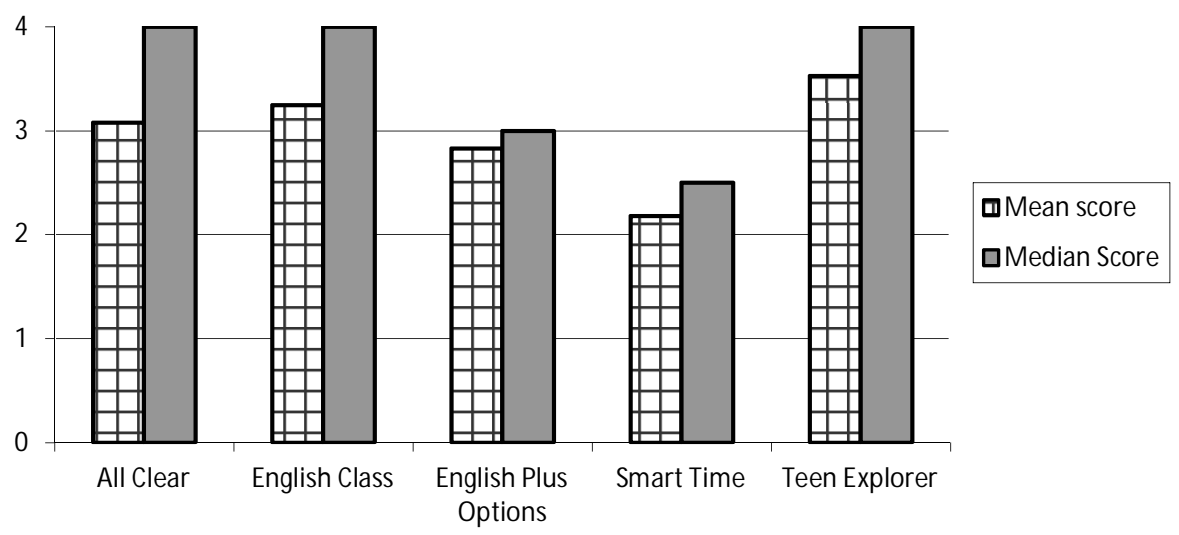

Figure 4: Mean and median scores of ICT-based tasks in coursebooks.

The overall point ratio for each coursebook is presented in Figure 4. below. The ratio was calculated by dividing the maximum number of points that each coursebook could potentially score by the number of points it actually scored (e.g. AC contains 5 ICT-based tasks, 5 multiplied by 8 categories and by 4 points equals 160 ). A perfect point ratio would therefore be ' 1 '.

\begin{tabular}{|l|c|c|c|}
\hline Coursebook & $\begin{array}{c}\text { Max. possible score per } \\
\text { coursebook }\end{array}$ & Score per coursebook & Point ratio \\
\hline All Clear & 160 & 123 & 0.76875 \\
\hline English Class & 192 & 156 & 0.8125 \\
\hline English Plus Options & 160 & 113 & 0.70625 \\
\hline Smart Time & 480 & 262 & 0.545833 \\
\hline Teen Explorer & 160 & 141 & 0.88125 \\
\hline
\end{tabular}

Figure 5: Point ratio of ICT-based tasks in coursebooks.

The results will now be described in more detail, taking each of the criteria in turn. 


\section{i. Encouraging students to:}

\section{1a. self-evaluate their own work}

In 6 tasks learners are invited to self-evaluate their own work by asking them to check the spelling and grammar (AC, EOP and TE), either on their own, in groups or with their teacher. The leader of this category, TE contains four (out of a total of five) tasks which were given the highest assessment.

1b. use different techniques of learning:

Nearly all tasks can be considered non-orthodox for they suggest creating posters, digital presentations or vlogs. A few times students are expected to write a quiz (EC) which is a very good example of an autonomous activity, since this way students take control of the lesson.

1c. shape creativity and positive attitude to learning a foreign language:

Thanks to many of the activities students are able to learn about the world while learning English. Repeating the same instructions over and over does not help, though (e.g. in EC four of the six tasks contain the exact same scheme of instructions; in ST all final instructions are practically the same: see $1 d$. below).

1d. learn about own strengths:

Most tasks include a present your work to the class rubric, which might lead to enhancing individual presentation skills, especially when pupils are instructed to vote for the most interesting work (EC) or to add their comments and ask their classmates for feedback (AC). Still, repeating the same present it to the class instruction (ST) may discourage learners.

1e. develop interests and passions:

The choice of topics is relevant to learners' age, (14-15-year-olds), for example, making videos, sport, music, dance, cooking, pets, or shopping. There are also fewer instances of other topics, including reading books, space travel, writing quizzes, future job, buildings or geography, especially in one of the coursebooks (ST).

\section{ii. The use of:}

2a. project-based learning:

Although only seventeen out of a total of thirty-six assignments pre-selected for the purpose of this study meet the rigorous requirements of PBL work (i.e. 
choosing the topic, defining project objectives, developing a schedule of activities, doing the project, project presentation and finally project evaluation - cf. Fried-Booth, 2002), they are all treated as potential PBL tasks. The reason for such a choice is justified by the lack of a clear-cut definition of what genuine PBL work actually is (cf. NCC, 2017: 8). After all, it largely depends on the teacher's creativity how to use a given coursebook task. The coursebook with the biggest number of ICT-based tasks contains no PBL work (ST); its 7 group work tasks out of a total of 15 exercises analysed cannot be considered project work for the instructions state only work in groups.

2b. authentic source materials from the Internet:

Not every exercise recommends searching the net for information, yet such tasks constitute the majority (e.g. find on the Internet, go online, or share it online in $\mathrm{AC}, \mathrm{EC}$, and $\mathrm{TE}$, respectively). This is the reason why such tasks were given a score of ' 4 '.

2c. tools based on information and communication technologies:

Since "the Internet" was included in the above category, suggestions to use other ICT tools were marked in this section, e.g. prepare a multimedia presentation / send the link (AC), or prepare a digital presentation (EC). M any instructions implicitly suggest using ICT, since the students are asked to e.g. add a video (EC), but neither mentions the equipment to be used. This way learners get an opportunity to select a mode of operation on their own - a certain way to develop autonomous behaviour. Some assignments analysed suggest using ICT tools, either by marking each of them with an ITC (ST) icon or by using ICT-related vocabulary (e.g. print the blog, EPO).

\section{d. Discussion}

Seventeen out of the total of thirty-six (47\%) tasks analysed, with explicit references to ICT, develop learners' autonomy to a satisfactory extent (set at a mean score of 2.75 and a median score at 3.5 out of 4 maximum points). The obtained results give strong grounds for a positive answer to the first research question - Is it possible to develop learner autonomy through coursebook tasks with explicit references to ICT?, although not all of the textbook assignments in question meet the research criteria, as can be seen in the diagrams above.

As far as the second research question (What aspects of learners' autonomy may be developed the most through such tasks?) is concerned, the emphasis is put on shaping creativity and a positive attitude to learning a foreign 
language (1c), developing interests and passions (1e) and using authentic source materials from the Internet (2b), since these received the highest mean scores of 3.6-3.7 points. The level of using different techniques of learning (1b) and applying ICT tools (2c) seems to be rather high as well (3.3 and 3.2), yet there is definitely some area for improvement. Similarly, learning about the learners' own strengths (1d) might be enhanced by diversifying some of the tasks, even though this category reached a relatively high mean score of 2.5. The focus on self-evaluation of students' work (1a, mean score of 1.1) seems insufficient and therefore this aspect could benefit from alterations in future editions of these textbooks.

The same seventeen tasks mentioned above were also found to use PBL work, which serves to underline its effectiveness. It should be mentioned that it is advantageous to place projects in a prominent place in the coursebook, either at the end of individual chapters (as in ST and TE), or in a completely separate segment at the end of the book (as in EPO). In order to allow both the student and the teacher to easily access them, it seems that project work should be appropriately marked, a characteristic missing in Smart Time.

Finally, three of the five coursebooks scored 4 (strongly agree) and above 3 (agree) on the median and mean scores, respectively (see Figure 3.). These three textbooks (AC, EC and TE) seem to foster student autonomy the most through ICT tools, since their overall ratio stands out above the 0.75 mark (rounded to $0.77,0.81$ and 0.88 , respectively; see Figure 5.). Even though it is clearly visible in Figure 4. that tasks from Teen Explorer have been awarded the biggest number of points, the last research question (Which textbook may help to foster student autonomy the most using ICT tools?) must remain unanswered. The reason lies in the fact that the qualitative research method described above has certain limitations since it presents only the researcher's own point of view. Therefore, a more complete picture of the usefulness of ICT tools in the field of fostering student autonomy might be obtained as a result of an additional examination. This could comprise a series of interviews with teachers currently using these books. Such teachers might be able to evaluate these tasks from a different, perhaps more practical perspective.

\section{Conclusions}

Foreign language lessons addressed at young teenagers in Poland still remain coursebook-based (Marczak et al., 2015: 81). The textbook basically determines the teaching content for $50 \%$ of teachers, while two out of three of them structure their lessons solely around it (Paczuska et al., 2014: 45). This may quite often translate into completing textbook tasks one after the other 
- an activity excessively dull, monotonous and predictable, both for learners and teachers. To make matters worse, the instances of using ICT tools, which would add variety to the lessons, come in small numbers (M uszyński, Campfield \& Szpotowicz, 2015: 31, 55).

Such problems might be overcome by the use of ICT-based tasks to a greater extent. This way the differences between better students and those with weaker language potential may be blurred, which may in turn result in greater involvement of the latter. In addition, the project method, being "widely recommended in the process of teaching critical thinking and problem-solving skills" (Beckett \& Miller, 2006: 4) may foster the development of learner autonomy through the use of planning, independent language work and "resourcefulness in collecting the necessary materials and their selection" (Figarski, 2003: 177). Finally, by allowing the pupils more freedom while working on projects, the teacher would provide them with partial control over the learning process (Kruk, 2009: 247).

The main difficulty in applying ICT-based PBL work in ELT in Poland may be the reluctance of primary education teachers to use projects due to having not enough time during lessons. Other obstacles include the lack of technological possibilities (mainly not being able to access the computer lab), and the certainty that students do not perform project tasks themselves (Sysło et al., 2014: 6). This is not surprising at all since the pupils are overloaded with homework, with an excess of knowledge to learn, and so are under a lot of stress (Lewicka-Zelentet et al., 2018: 83). Perhaps overcoming these hindrances and introducing pupils to more autonomous learning by the means of ICT-based project work might ease their pain a little?

\section{Acknowledgement}

This article has received financial support from the Polish M inistry of Science and Higher Education under a subsidy for maintaining the research potential of the Faculty of Philology, University of Bialystok.

\section{BIBLIOGRAPHY}

Beckett G.H. \& Miller P.C. (eds.) (2006), Project-based Second and Foreign Language Education: Past, Present and Future. Greenwich: Information Age Publishing Inc.

Common European Framework of Reference for Teaching Languages: Learning, Teaching, Assessment (2001), Council of Europe. Online: https://rm.coe.int/ $1680459 f 97$ [access date 14.03.2018]. 
Droździał-Szelest K. (2008), Trening strategiczny na lekcji języka obcego - mit czy rzeczywistość? (in) Pawlak M. (ed.), Autonomia w nauce języka obcego - co osiągnęliśmy i dokąd zmierzamy. Poznań - Kalisz - Konin: Wydział Pedagogiczno-Artystyczny UAM w Kaliszu oraz Państwowa Wyższa Szkoła Zawodowa w Koninie, pp. 405-416.

Dörnyei Z. (2007), Research Methods in Applied Linguistics, Oxford: Oxford University Press.

Dudeney G. \& Hockly N. (2007), How to Teach English with Technology. Harlow: Pearson Education Limited.

Dylak S. (2012), M etoda projektów płaszczyznq wzajemnego dostrajania się szkoły i "digital natives"..., "Neodidagmata", No. 33/34, pp. 167-181.

Ellis R. (1997), The Empirical Evaluation of Language Teaching Materials (in) "ELT Journal", No. 51/1, pp. 36-42.

Fried-Booth D.L. (2002), Project Work. $2^{\text {nd }}$ edition, Oxford: Oxford University Press. Gajek E. (2008), Edukacja językowa w społeczeństwie informacyjnym. Warszawa: Instytut Lingwistyki Stosowanej Uniwersytetu Warszawskiego.

GajekE. \& Michońska-StadnikA. (2017), Strategie uczenia się języków obcych w środowisku cyfrowym. Warszawa: Instytut Lingwistyki Stosowanej WLSUW.

Habrat A. (2008), Czy podręcznik pomaga wdrażać ucznia do autonomii? Ewaluacja wybranych podręczników do nauki języka angielskiego w starszych klasach szkoły podstawowej pod katem autonomizacji (in) Pawlak M. (ed.) Autonomia w nauce języka obcego - co osiągnęliśmy i dokąd zmierzamy. Poznań - Kalisz - Konin: Wydział Pedagogiczno-Artystyczny UAM w Kaliszu oraz Wydawnictwo PWSZ w Koninie, pp. 281-290.

Hofman A. (2008), Technologia informacyjna w promowaniu autonomii w świetle wielorakich perspektyw inteligencji uczniów (in) "Języki Obce w Szkole", No. 6, pp. 63-68.

Holec H. (1981), Autonomy and Foreign Language Learning, Oxford: Pergamon. Konsek K. (2004), Rozwijanie autonomiczności poprzez Internet (in) Pawlak M. (ed.), Autonomia w nauce języka obcego. Poznań - Kalisz: Wydział Pedagogiczno-Artystyczny UAM w Poznaniu, pp. 265-275.

Krajka J. (2007), English Language Teaching in the Internet-assisted Environment - Issues in the Use of the Web as a Teaching M edium, Lublin: Wydawnictwo UMCS.

Kruk M . (2009), Rola nauczyciela i ucznia w klasie językowej a rozwijanie autonomii ucznia za pomocq Internetu (in) Pawlak M., Derenowski. M., Wolski. B. (eds.), Problemy współczesnej dydaktyki języków obcych. Poznań - Kalisz: Wydział Pedagogiczno-Artystyczny UAM w Kaliszu, pp. 237-249.

Kruk M. (2011), Rozwijanie autonomii ucznia za pomoca zasobów Internetu prezentacja wyników jakościowych badania eksperymentalnego (in) 
Evaluation of the use of information and communication technology in English...

Pawlak M. (ed.), Autonomia w nauce języka obcego - uczeń a nauczyciel. Poznań - Kalisz - Konin: Wydział Pedagogiczno-Artystyczny UAM w Kaliszu oraz Wydawnictwo PwSZ w Koninie, pp. 313-326.

Kusiak-Pisowacka M. (2015), Ewaluacja podręcznika w nauczaniu języków obcych (in) “Lingwistyka Stosowana”, No. 4, pp. 65-75.

Lewicka-Zelent A., Zubrzycka-Maciąg T., Kwiatkowski P., \& Trojanowska E. (2018), Sytuacja uczniów klasy VII zreformowanej szkoły podstawowej, Raport Rzecznika Praw Dziecka przygotowany na podstawie sondażu opinii młodzieży, rodziców, nauczycieli i dyrektorów szkół. Online: http://brpd.gov.pl/aktualnosci-wystapienia-generalne/sytuacjaszkolna-uczniow-klas-vii-raport-rpd [access date 01.09.2018].

Malinowski P.J. (2018), Application of Information and Communication Technology in English Coursebooks (in) "Crossroads", No. 22, pp. 49-68, Online: http://www.crossroads.uwb.edu.pl/wp-content/uploads/2019 103/crossroads22.pdf [access date 25.06.2019].

Malinowski P.J. (2019), Rozwijanie kompetencji komputerowych i informacyjnych w glottodydaktyce na przykładzie podręczników do nauki języka (in) "Zeszyty Naukowe UR. Seria Filologiczna. Glottodydaktyka", No. 11, Vol. 104/2019, pp. 136-147.

Majer H. (2015), Podręczniki elektroniczne drogq do autonomii ucznia? (in) Pawlak M. (ed.), Autonomia w nauce języka obcego - techniki, strategie, narzędzia. Konin - Kalisz - Poznań: Wydawnictwo PWSZ w Koninie oraz Wydział Pedagogiczno-Artystyczny UAM w Kaliszu, pp. 135-148.

Marczak M., M uszyński M., Campfield D., Gajewska-Dyszkiewicz A., Paczuska K., Pitura J. \& Szpotowicz. M. (2015), Realizacja podstawy programowej dla języka obcego nowożytnego (in) Sitek M., Choińska-M ika J. (eds.), Realizacja podstawy programowej kształcenia ogólnego. Wnioski z badań przeprowadzonych przez Zespół Dydaktyk Szczegółowych IBE. Warszawa: Instytut Badań Edukacyjnych, pp. 68-85.

M cDonough J. \& Shaw C. (1993), Materials and Methods in ELT. Oxford: Blackwell. M uszyński M., Campfield D. \& Szpotowicz M . (2015), Język angielski w szkole podstawowej - proces i efekty nauczania. Wyniki podłużnego badania efektywności nauczania języka angielskiego (2011-2014), Warszawa: Instytut badań Edukacyjnych.

Paczuska K., Kutyłowska K., Gajewska-Dyszkiewicz A., Ellis M., \& Szpotowicz M. (2014), Język angielski w gimnazjum. Raport czq̨stkowy z I etapu badania uczenia się i nauczania języków obcych w gimnazjum, Warszawa: Instytut Badań Edukacyjnych.

Podstawa programowa kształcenia ogólnego. Szkoła podstawowa. język obcy nowożytny (2017), M inisterstwo Edukacji Narodowej/Ośrodek Rozwoju 
Edukacji. Online: www.men.gov.pl/wp-content/uploads/2011/02/men _tom_3.pdf [access date 14.03.2018].

Reforma edūkacji 2017. Zmiany w kształceniu ogólnym. specjalnym i zawodowym oraz w obszarze wychowania i profilaktyki (2017), Ministerstwo Edukacji Narodowej/Ośrodek Rozwoju Edukacji. Online: https:// www.o re.edu.pl/wp-content/uploads/2018/03/reforma-edukacji-2017.-zmia ny-w-ksztalceniu-ogolnym-specjalnym-i-zawodowym-oraz-w-obszarze-wy chowania-i-profilaktyki.pdf [access date 01.09.2017].

Sysło M , Jasiewicz J., Sijko K., Biedrzycki K., Kaczan R., Piechociński T., Rycielski P.

\& Rycielska L. (2014), Kompetencje komputerowe i informacyjne młodzieży w Polsce. Raport z międzynarodowego badania kompetencji komputerowych i informacyjnych ICILS2013, Warszawa: Instytut Badań Edukacyjnych. Skweres A. (2011), Podcast jako atrakcyjne medium w propagowaniu autonomicznego uczenia się języków obcych (in) Pawlak M. (ed.), Autonomia w nauce języka obcego - uczeń a nauczyciel. Poznań - Kalisz - Konin: Wydział Pedagogiczno-Artystyczny UAM w Kaliszu oraz Wydawnictwo PwSzZ w Koninie, pp. 337-344.

Strzemeski K. (2011), Autonomizacja studentów poprzez ich samodzielnq prace z podcastami (in) Pawlak M. (ed.), Autonomia w nauce języka obcego uczeń a nauczyciel. Poznań - Kalisz - Konin: Wydział Pedagogiczno-Artystyczny UAM w Kaliszu oraz Wydawnictwo PwSzZ w Koninie, pp. 327-336. Szpotowicz M . \& Muszyński M. (2015), Jak wyglqqdajq lekcje języka angielskiego w szkole podstawowej? Wyniki Badania efektywności nauczania języka angielskiego (BENJA) (in) "Języki Obce w Szkole", No. 4, pp. 98-104.

Widła H. (2009), Przykłady metod pracy wykorzystujacych technologię informacyjnq na lekcji języka (in) Pawlak M ., Derenowski M., Wolski B. (eds.), Problemy współczesnej dydaktyki języków obcych. Poznań - Kalisz: Wydział Pedagogiczno-Artystyczny UAM w Kaliszu, pp. 183-192.

Wilczyńska W. \& M ichońska-Stadnik A. (2010), M etodologia badań w glottodydaktyce. Wprowadzenie. Kraków: Wydawnictwo AVALON, Kraków.

Wykaz podręczników do nauki języka angielskiego dopuszczonych do użytku w nowych typach szkół (2017), Ministerstwo Edukacji Narodowej. Online: https://podreczniki.men.gov.pl/wykaz_dopuszczone_lista5.php [access date 31.08.2017].

\section{COURSEBOOKS ANALYSED}

Bandis A., Shotton D. (2017), Teen Explorer. Podręcznik dla kasy 7. Warszawa: National Geographic Learning/Nowa Era. 
Evaluation of the use of information and communication technology in English...

Evans V., Dooley J. (2017), Smart Time 1 Do nowej podstawy programowej. Newbury: Express Publishing.

Hastings B., M cKinley S., Tkacz A. (2017), English Class A2+. Warszawa: WSiPPearson Central Europe.

Howarth P., Reilly P., Morris D. (2017), All Clear. Warszawa: M acmillan.

Puchta H. (2017), Citizen Z. Warszawa: Cambridge University Press/PWN.

Wetz B., Pye D. (2017), English Plus Options. Oxford: Oxford University Press. 